\begin{tabular}{c}
\hline KEMAS 13 (3) (2018) 356-365 \\
Jurnal Kesehatan Masyarakat
\end{tabular}

\title{
BENEFIT OF CHILDBIRTH CARE COUNSELING FOR MOOD OF POSTPARTUM PERIOD
}

\author{
Yuni Purwati ${ }^{\circledR}$ Kustiningsih $^{1}$ \\ ${ }^{1}$ Faculty of Health Science, Universitas ‘Aisyiyah Yogyakarta
}

\begin{tabular}{l} 
Article Info \\
\hline Article History: \\
Submitted September 2017 \\
Accepted October 2017 \\
Published March 2018 \\
\hline Keywords: \\
Counseling, Mood Disor- \\
der, Postpartum Mothers \\
\hline DOI \\
https://doi.org/10.15294/ \\
kemas.v13i3.11275
\end{tabular}

\begin{abstract}
Postpartum mood disorder experienced by mothers was characterized by severe fatigue, poor concentration, tiredness, sadness, and anger at her husband. This postpartum mood disorders could progress to postpartum depression and postpartum psychosis. Childbirth care counseling was an attempt to allow mothers to adapt to her postpartum condition. The objective of this research was to identify the effect of childbirth care counseling on postpartum mood changes at Wates General Hospital, Kulonprogo. This research used pre-experimental design with post test. We used purposive sampling to obtain 20 respondents in the experimental group and 20 respondents in the control group. Moreover, EPDS instruments were also used in this research. Saphiro-Wilk normality test resulted in $\mathrm{SD}=0.000<0.05$. The Mann-Whitney test resulted Z-2.054 $>$ t-table, $\alpha=0.040<0.05$. We found that there was a significant benefit of childbirth care counseling on postpartum mood changes at Wates General Hospital, Kulonprogo. The significance of this research is that health workers in prenatal units should provide counseling about postpartum care to mothers in their third trimester.
\end{abstract}

\section{Introduction}

Pregnancy and childbirth are an important experience for mothers and it have different meanings for every mother and her family. This occasion is a very positive and pleasant transition phase to a new stage in the life cycle for mothers. However, this can also inflict stress resulting in anxiety, disappointment, and other psychological changes (Castalino, 2014).

Pregnancy also highly depresses some mothers in spite of giving extraordinary happiness. The role of becoming a mother not only makes her feel fully steady in living her life and increases her confidence, but can also undergo several other roles both in the family and in the social environment. Broadly speaking, becoming a mother not only make a woman feels eager but also makes her care for her baby. However, some mothers actually feel sad, angry, upset, tired, meaningless, and desperate in the days after childbirth. Continuous fatigue reduces the physical and mental capacity. This could developed to reluctance in looking after the baby or even desire to murder the baby. These various stress indicators cause psychological problems during pregnancy until birth (Reitmanova, 2009). Westall (2011), stated that postpartum mood disorder and postpartum depression are triggered by the mothers being anxious and not getting a good support system.

Postpartum mood disorder is a temporary disorder experienced by mothers who have just given birth. It often occurs in 
first childbirth during the first 1-10 days or 2 weeks, and causes postpartum depression. Signs and symptoms of mood disorder are sadness, irritation, liability, and headache. If the condition lasts longer, it will develop into severe postpartum disorder. The symptoms are profound sadness, anger, depression, sensitivity, guilt, fatigue, anxiety, and carelessness toward baby and self (Reitmanova, 2009).

The effects of postpartum mood disorder are anxiety in socializing with others, failing to look after themselves and their babies, and failure in breastfeeding. These conditions cause problems in the relationship between mothers and their babies, such as the psycho-pathological disorders and late development of babies. The tendency of profound sadness emerges that they becomes less sensitive to provide positive care for their babies. Consequently, the babies did not learn to develop positive effects and felt discomfort in their development process. The babies tend to have orientation disorder, depression effects, irregular sleep, verbal development problems, behavioral disorders, delay of scholasticism development, and other types of physical disorders. If postpartum mood disorder progress into postpartum depression, the atmosphere of sadness becomes more intense than postpartum blues. Postpartum blues symptoms have adverse effects on mothers, babies, and family members, causing difficulty in social participation. The symptoms not only affect mothers in the form of suicide attempt or desire to murder the baby, but also adversely affects the whole family because the mother tends to withdraw and refuse to care for the baby that the baby suffers from lack of affection. According to Westall (2011), postpartum mood disorder influences interaction between babies and their mothers during the first year i.e., the baby does not received enough stimulation, the mothers failed to undergo daily activities, relationship difficulties from others (family and friends), increased risk of using drugs which increase the risk of postpartum psychotic depression. The effects on babies are that they cry more, had sleeping and eating problems, and suffered infanticide.

Kusumastuti (2013), reported that $10 \%$ of mothers have post-partum psychological disorder, $50-58 \%$ experiences a type of post- partum blues, and $12 \%$ who have postpartum blues developed postpartum depression during the postpartum period. Hormonal and postpartum maternal life changes are considered a trigger for depression. It is estimated that about $50-70 \%$ of mothers showed early postpartum blues symptoms. However, it sowly disappears due to appropriate adaptation and family support. The National Mental Health Association (2009) in Segre (2010), stated that $80 \%$ of mothers who give birth for the first time have these symptoms.

Another causes of postpartum mood disorder in Taking In Phase is a psychological factor in the process of pregnancy and childbirth, that is the emotional mother at the time of childbirth. According to Lesser and Keane, there are four maternal wishes in childbirth: being accompanied by the dearest person, received pain-reducing means, have a sense of security from the nearest person to the baby and receives the baby, and gets attention, affection, and appreciation by the nearest person when giving birth. When the desire of the mother is unmet, it will affect the psychological condition of the mother after childbirth. The period of taking in phase is the beginning of the crisis period; new responsibilities arise and often require modification or addition of previous behaviors. This phase is also a transition from before being a parent to becoming parents. The period of parenthood is more accurately considered a process rather than a state; a process that begins during pregnancy and develops rapidly after birth (Kirana, 2015).

Postpartum blues is the most common type of depression in postpartum period. It is an adaptation disorder on childbirth incident that mothers have a depression mood. This reaction can occur any time after the mothers gave birth. However, it often occurs on day 3 or 4 after postpartum. Moreover, 3 out of 4 mothers have postpartum blues. Mothers feel overwhelmed and easily cry without any apparent reason. Mothers show severe fatigue, poor concentration, lost of sensitivity, deep sadness, and hostility to her husband. Kusumastuti (2013), reported relationship between husband and wife became difficult due to severe postpartum blues and postpartum depression. 
Researchers have proposed several solutions to reduce postpartum depression , such as antenatal health education, house infant care, and postpartum depression information through booklets and learning methods on appropriate caring of babies, and important support by husband from pregnancy until infant care. In addition, counseling is also important to prepare the maternal psychology in accepting the change of role (Setiawati, 2016).

Counseling is a process of discussion conducted by counselor and counselee to find the right solution to overcome problems. Based on preliminary study in Flamboyan Room at Wates General Hospital, Kulonprogo, 1 postpartum mother refuses to care for her baby. She was sleepy if she had to take care of her baby at midnight so her husband look after the baby instead. The mother said she has never received information from health workers on how to care for the baby and herself after giving birth.

Based on the background described above, we are interested in conducting a study on "The Implementation of Childbirth Care Counseling on Postpartum Mood Disorder in the Wates General Hospital, Kulonprogo." The general objective of this study was to identify the effect of childbirth care counseling on postpartum mood disorder patients in Wates General Hospital, Kulonprogo. Moreover, the specific objective was to identify the changes in postpartum mood disorder patients after implementation of counseling in Wates General Hospital, Kulonprogo. The changes in postpartum mood disorder patients appear through childbirth for postpartum care in Wates General Hospital, Kulonprogo. We expect our study can increase the nursing science database, which is not only related to postpartum mood disorder on maternity care but is also related to the standard operational procedure on maternity care service unit.

Method

The method of this research was experimental method with the aim of identifying arising symptoms or effects from a particular treatment. This research used post-test only design where we compared and tested the differences between groups after the treatment was given.
Childbirth care counseling was information provision by educating about technique on childbirth care and baby care. It is carried out by health workers accompanied by the mother's husbands. The counseling included self-care, perineum, gymnastics, breast care, nutrition fulfillment, and sexual fulfillment. The mothers and their husbands were taught about bathing, umbilical cord care, changing clothes, and breastfeeding or immunization. These were carried out for 60 minutes on every mother who gave birth for the first time at day0 in the experimental group.

Changes on postpartum mood were measured using the Edinburgh Postnatal Depression Scale (EPDS) questionnaire. The experimental group respondents were asked to fill out the questionnaire on the $2^{\text {nd }}$ day of postpartum. The control group respondents were also asked to fill out the Edinburgh Postnatal Depression Scale (EPDS) questionnaire at the same time as the treatment group with provided guidance without any postnatal gymnastic training. The assessment criteria were as follows: 66-90 was considered good mood; 42-66 was poor mood (mild mood); and 18-42 was bad mood (severe depression).

The population of this research is all postpartum mother in PKU Muhammadiyah Bantul Hospital. The sampling technique was purposive sampling based on requirements or criteria set by researchers. The number of samples in this research was 40 postpartum mothers consisting of 20 people as respondents of the experimental group and 20 people as the control group respondents. Respondents of this research were parturial mothers with a normal childbirth and caesarean section at day0 postpartum.

The tool used to collect postpartum mood data was Edinburgh Postnatal Depression Scale (EPDS) questionnaire. This questionnaire was given to the experimental group two days after postpartum care counseling. The control groups was also given the EPDS questionnaire but did not received postpartum care counseling beforehand.

Parametric analysis test was conducted with the assumption that each variable was analyzed through normal distribution. Prior to 
parametric statistical test, data normality test was conducted using one sample KolmogorovSmirnov test. The result was $\alpha>0.05$ so Ho was accepted and $\mathrm{Ha}$ was rejected. It meant the data had normal distribution, therefore, independent t-test was used. If the data was not normally distributed, Mann-Whitney test was used instead.

\section{Result and Discussion}

There were 16 (80\%) and 11 respondents $(55 \%)$ in healthy productive age category in the experimental and the control group, respectively, as shown in Table 1 . The respondents in the healthy productive age category were 20-35 years old. Most mothers who were pregnant and gave birth were in this age category. Respondents in this age category were also more prepared to face pregnancy and childbirth. Furthermore, an optimal period to take care of the baby was at the age of 20-35 years, so the mothers were mentally-prepared in having childbirth, self-care, and baby care (Kusumastuti, 2013).

In this study, respondents aged 20 years had good mood, likely because the age is a risky age for women to give birth. Our result indicated an influence between age and mood disorder during childbirth. This is in accordance with a study by Irawati (2014), which reported that the age of adolescence or less than 20 years is a trigger factor of postpartum mood disorder. Situational crisis situations, experiences regarding parental readiness, role burden in the social environment can cause problems in women giving birth, including those younger than 20 years old.

Postpartum maternal parity were based on the postpartum maternal parity status on the experimental group and primipara parity status on the controlled group. There were $15(75 \%)$ and $16(80 \%)$ primipara in the experimental and control group, respectively. Postpartum mood was related to parity status. Primipara mothers had less experience in facing childbirth and looking after their baby care compared to multipara mothers who have had experienced childbirth and baby care. However, past childbirth experienced and poor parturient conditions affected mood disorders in the current parturient period and their baby care (Castalino, 2014).

One respondent with a good mood was a primipara mother. Irawati (2014), showed that $63.6 \%$ respondents who experienced postpartum blues were primipara. There is a relationship between parity and postpartum incidence with $p=0.027$. This is because the duration, complication and the labor itself can psychologically affect the mother; the greater the physical trauma, the greater the psychological trauma that arises. And this is increasingly felt in women who gave birth for the first time. Changes during pregnancy, especially hormone increase, can increase anxiety and fear of

Table 1. Characteristics of the Respondent

\begin{tabular}{llllll}
\hline \multirow{2}{*}{ Age Characteristics } & \multicolumn{2}{c}{ Experimental Group } & \multicolumn{2}{c}{ Control } & Group \\
\cline { 3 - 6 } Age & Freq & \multicolumn{2}{c}{$\%$} & Freq & $\%$ \\
\hline \multirow{4}{*}{ Parity } & Less than 20 years old & 4 & $20 \%$ & 9 & $45 \%$ \\
& 20-35 years old & 16 & $80 \%$ & 11 & $55 \%$ \\
& Total & 20 & $100 \%$ & 20 & $100 \%$ \\
\multirow{3}{*}{ Type of } & Primipara & 15 & $75 \%$ & 16 & $80 \%$ \\
labor & Multipara & 5 & $25 \%$ & 4 & $20 \%$ \\
& Total & 20 & $100 \%$ & 20 & $100 \%$ \\
Mood & Spontaneous labour & 8 & $40 \%$ & 7 & $25 \%$ \\
& Cesarean delivery & 12 & $60 \%$ & 13 & $75 \%$ \\
& Total & 20 & $100 \%$ & 20 & $100 \%$ \\
& Passable & 1 & $5 \%$ & 6 & $30 \%$ \\
& Good & 19 & $95 \%$ & 14 & $70 \%$ \\
& Total & 20 & $100 \%$ & 20 & $100 \%$ \\
\hline
\end{tabular}

Source : Primary Data 
Table 2. Mann Whitney Statistical Analysis Result

\begin{tabular}{ll}
\hline & Postpartum Mood on Mothers in Experimental and Control Group \\
\hline Mann-Whitney U & 150.000 \\
Wilcoxon W & 360.000 \\
Z & -2.054 \\
Asymp. Sig. (2-tailed) & .040 \\
Exact Sig. [2*(1-tailed Sig.)] & $.183^{\mathrm{a}}$ \\
\hline
\end{tabular}

Source : Primary Data

accepting new roles into situational crises that can lead to postpartum mood problems.

The age of 35 years is often referred to as the deadline, as beyond that age, pregnancy pose a greater risk. The maternal mortality rate rises steadily from 9 per 100,000 at the age of 25-29 years to 66 per 100,000 after the age of 40 years. This indicates that the risk of maternal mortality increases rapidly with increasing age of the mother. Older mothers are more susceptible to diabetes and high blood pressure. Infant from an older mother had increased likelihood of chromosomal defects, such as Down syndrome. Mothers who deliver their first child over the age of 35 are more likely to have difficulty in labor, unlike older women who have previously gave birth (Ichsan, 2015).

In this study, 12 and 13 respondents in the experimental and control group, respectively, have spontaneous labor. The adaptation process of spontaneous postpartum mothers is relatively faster than post-caesarean section mothers. Spontaneous postpartum mothers have faster early mobilization. They can immediately breastfeed their baby, and they have more optimal husband assistance. This activity can also speed up mother's recovery and uterine involution process. This results in better maternal psychological adaptation during childbirth.

However, in cesarean delivery, postpartum pain and physical limitations will hinder postpartum mother in taking care of themselves and their babies. Mothers often feel fearful and anxious about their physical condition, thus reducing the desire to immediately care for her baby. Asmuji (2016), mentioned that postpartum mother of post caesarean section who received information about self and baby care before delivery had decreased maternal anxiety and fear until childbirth. In addition, the husband's continuous support can improve psychological readiness in mothers. In this study, we proved that post caesarean section respondent can have good mood; 1 post-caesarean section respondent had good mood because her age was under 20 years old.

Postpartum mood changes on the experimental and control groups appeared after counseling was given on postpartum and baby care. There were 19 respondents (95\%) who showed good mood, but 1 respondent (5\%) showed good enough mood. In the control group, there were 14 respondents (70\%) who showed good mood, but 6 respondents (30\%) showed good enough mood.

Prior to statistical tests, data normality test using Saphiro-Wilk was conducted on both group. The result for both group was 0.00 , which was lesser than $\alpha=0.05$, so the data did not have normal distribution. Therefore, a nonparametric test, that is Mann-Whitney test, was carried out as shown in the following table:

Based on the tendency of cross tabulation result in Table 2, the Mann Whitney statistical analysis result was Z-2.054. This score was greater than the $t$-table. The significance level (0.040) was smaller than $\alpha=0.05$. According to this result, we concluded that Ho was rejected and $\mathrm{Ha}$ was accepted. It indicated that childbirth and baby care counseling significantly affect postpartum mood changes for the better.

We found 14 respondents (70\%) in the control group and 19 respondents (95\%) in the experimental group with good mood, indicating that postpartum maternal mood was in good condition. Basically, respondents had good mood because mothers who suffered from postpartum mood disorder were supported by her husband and mother. Family support 
provided comfort to the postpartum mother According to Ichsan (2015), husband and family support could foster self-confidence in postpartum mothers to face childbirth and to care for the baby. There are families who were always ready to help for postpartum recovery and care of the baby. It reduced feelings of anxiety, depression, and lack of attention from the family.

Family social support from close person such as husbands, parents and siblings who care for, respect, and love them is beneficial. Education support about postpartum and baby care is needed by mothers because they have no experience in caring for their babies. Instrumental support is needed for the mother to provide ease in self and baby care. Social support is also needed for postpartum mothers, especially at their first time giving birth. Assessment support in the form of feedback on how they take care of themselves and their baby is also needed in the first time mothers. Anxiety that occurs in the puerperal mother generally occurs in primipara. This condition requires support from the closest person. The closest person emotionally is the husband. Support from the husband will be perceived positively and make the mother felt comfortable, appreciated, and loved (Marmer, 2016). So in this study, counseling package about parenting and infant care is given to postpartum mother accompanied by her husband.

We analyzed the difference in posttest score between experimental group, who received childbirth care and baby care counselling, an the control group who was not given the counselling. The score of the experimental group tend to be better. Counseling on the respondents and her spouse was a process of providing assistance through an expert's interview (counselor) to the client who had problems. In this study, the problems were the postpartum mother and the care of their babies. Discussion, interview, information, and decision making was done between counselor and counselee. The implementation of the counseling process until decision making meant that the problems experienced by the client could be resolved and decisions had been made in order to overcome health problems.

Counseling was carried out for the improvement of the client because the client's attitude improvement through interaction for a certain time was the priority of counseling. Through direct face-to-face approach, improvements on thinking, feeling, attitude, and behaviour appeared. The client was able to straighten the problem, realized the lifestyle, and reduced the negative feelings and inferiority. Moreover, it also corrected behavior on the environment so that clients could direct their behavior and interests in social activities for meeting the needs of childbirth and baby care.

This counseling helped the growth and development of her thinking and behavior. This condition encouraged her to develop social skills, learn to control emotions, and develop positive self-concept. It reduced anxiety or mood disorder at postpartum as indicated by changes such as, being understandable, positive, and caring for the baby (Basten, 2009).

The postpartum period was a period of adaptation for mother and baby. The mother had a responsibility to meet her family need and to care for her baby. Failing to understand the baby led to fatigue. Reitmanova dan Gustafson (2009) stated that mothers were very tired and worried about their baby's needs, and required a rest after giving birth. Isni (2016), stated postpartum mood disorders and postpartum depression emerge when mothers felt a sense of anxiety and lacked good support.

Suryani (2008), in Kusumastuti (2013), stated that mothers could have psychological problems and postpartum depression because they were socially alienated and easily felt uneasy in every daily activity. In this study, family assistance played an active role to improve mood during the postpartum period through counseling. As the family grew confident, especially the husbands, postpartum mothers could anticipate normal parturient period.

Healthy productive age (20-35 years old) were the right time to conceive and gave birth. At this age group, respondents were better prepared to face pregnancy and childbirth. Furthermore, the healthy productive age was the optimal period to care for a baby so that mothers can be more mentally prepared to face childbirth, self-care, and baby care (Ichsan, 
2015). In addition, increasing maternal age affected not only emotional maturity but also engagement and satisfaction to care for mothers and their baby. Similarly, low parity (primipara mothers) tends to experience psychological problems, since multipara mothers have had previous experiences of pregnancy and childbirth. However, the psychological problems of multiparous mothers were not only due to troublesome and traumatic childbirth but also due to the many children they have, the birth of the baby not meeting their expectation, fear in looking after and educating the child properly, being unable to care for their children, and worry about their future (Kirana, 2015).

In our study, we found 6 respondents (30\%) with good mood in the control group without counseling, and 1 respondent (5\%) with good enough mood in the experimental group. This was the respondents who answered the first item (feeling nervous and restless, especially when caring for the baby). Moreover, these respondents also answered the second item (having fear and worries about their condition and the baby.

Respondents also answered the sixth (feeling stomachache) and the seventh item (feeling weak and tired in recent days). This was consistent with Larson-Meyer's statement, he said that mothers were in fear-tensionpain cycle after giving birth. The pain during uterine contractions caused tension. Tension lead to the release of biogenic amine enzymes (three catecholamines) and serotonin that stimulated central nervous neurotransmitters which lead to a state of stress. Stress caused fear, which increased pain and can eventually triggers mood disorders. Symptoms of mood disorder are as follows: poor appetite, sadness, insomnia, anorexia, disturbed by physical changes, difficulty concentrating, self-injury, anhedonia, guilt, weakness in will, hopelessness of the future, and not wanting to relate to others (Rusli, 2011).

Postpartum mother experienced physiological adaptation (abdominal pain) due to uterine involution which disturbed daily activities and interactions with the baby. Mothers were also still in a weak condition because of exhaustion after childbirth. Rubin (1963) in Purwati (2015), explained that respondents were still having psychological adaptation on the first day of postpartum. Consequently, the mother become selfish and passive to her environment, focuses on fatigue, had no desire to take the initiative to interact with the baby, and desperately needing others in their daily lives.

Inability to adapt to the new roles and activities is likely due to a psychological disorders with varying symptoms that are usually called postpartum mood disorders. This often occurred to mothers too young of age. In this study, there were 4 and 9 mothers aged less than 20 year in the experimental group and in the control group, respectively. Physically, adolescents are ready to conceive and give birth. However, they are psychologically unprepared to take care of their baby, as well as their household. Adolescence is a time someone began to be interested in the environment outside the family. Teenage mothers at this time certainly have different activities compared to before becoming a mother. For example, a teenage mother is busy with her baby when she is previously free to play and hang out with other teenagers. This preoccupation with her baby may exert emotional pressure to her, increasing her risk of postpartum mood disorders (Segre, 2010).

The differences in the experimental and control groups on postpartum mood disorder were consistent with Purwati (2015) and Musfiroh (2014) study. It meant that the provision of well-planned information with clear media could improve a person's attitudes and behaviors. It was also linked to the counseling of the experimental group in this study. The understanding given to patients with emotional problems and incomprehension led to rational instead of emotional control. Patients became more capable of forming and maintaining a meaningful and satisfying relationship with others. Moreover, they also became more sensitive on how to think or feel. Furthermore, they were also able to develop a more accurate sense of self-acceptance.

The development of a positive selfattitude appeared in line with the ability to explain the experience that had always been the subject of self-criticism and rejection, to initiate the movement toward the potential fulfillment 
or integration acceptance of previous selfconflict, and to help the client achieve a higher state of spiritual consciousness, and to find specific decision that could not be solved on its own.

Thasim in Woro (2017), stated that one could grasp ideas and techniques used for understanding and controlling behavior by learning and mastering social and interpersonal skills so that irrational beliefs or unadjusted thought patterns could be modified to avoid self-destructive behavior.

Duman (2012), explained that postpartum mothers who received postpartum counseling were able to deal with self-care and baby care through breastfeeding and preparation in overcoming anxiety. According to Spaulding (2016), childbirth counseling was more useful if it is provided before mothers give birth. As the mothers have not faced childbirth yet, they can carefully plan how and who will help take care of herself and her baby and prepare for postpartum psychological problems. The nurses provided continuous health counseling to the patients for 24 hours so that anxiety, restlessness, and other postpartum maternal psychological disorders are overcome during the postpartum (Segre, 2010).

Postpartum mothers who receive counseling on postpartum care will behave well in taking care of herself and her baby. By maintaining personal hygiene, nutritious food, early mobilization and breastfeeding exercise, mother can recovery quickly and facilitate breastfeeding. Early mobilization of the puerperium is useful in ensuring breastfeeding success. Immediate mobilization will involve physical activity that will increase the muscle demand oxygen. Meeting this demand requires an increase in circulation which will involve the nervous system. Intermediaries will connect to the hypothalamus, specifically posterior pituitary, to release oxytocin which will be transported by blood to the breast to stimulate the myoepithelial cells to form the ductus dialveoli so colostrum and milk may pass more smoothly (Kendall, 2013 in Sunesni, 2015).

Setiawati (2016), said that a healthy counseling had an important role in cognitive process. It is important in understanding, attitudes, and changes in behavior, including the behavior of the family and the respondents experiencing post-childbirth and childbirth. Counseling for the respondents and the support of husband helped reduce postpartum mood disorder and provided a sense of comfort and happiness that the mothers went through childbirth well (Isni, 2016).

This counseling is performed on postpartum mother who was accompanied by their husband. Husband's support is a form of social interaction in which there is a mutual relationship where they help each other. The aid will place the individuals involved in the social system that they will eventually be able to give love, attention and sense of attachment to both the family or spouse. Husband support is very important and can not be underestimated in building a positive atmosphere when the wife felt exhausted in the first few days. Therefore, the support or positive attitude of the spouse and family will give its own strength for the postpartum mother. The husband plays an important role in the occurrence of postpartum blues. The husband is expected to realize that the wife desperately need support at a certain moment and to be present when the wife needs him. Aside from psychological support, physiological, assessment, information and financial support is needed by the wife. The provision of all those should make the wife feels comfortable and can deliver well. Husband support is an important coping strategy when under stress and serves as a preventive strategy to reduce stress and its negative consequences. Therefore, the support of husbands is needed by women after experiencing childbirth (Irawati, 2014).

We are faced with unpredicted obstacles in this study. In the planning, the respondents were postpartum mothers (primiparas respondents). However, we also added multiparous respondents who had a history of abortion in the previous pregnancies or postpartum mothers who had a second child more than 7 years ago. In addition, we are unable to implement counselling in an ideal way (the counseling atmosphere should be calm and counselors and counselees could directly talk to each other, but these conditions were unfulfilled due to the room being in a class 3 setting where multiple patients were in the same room). We 
modify and eventually conduct the counseling in the care room. Moreover, the caring process for the baby was also directly done with the baby instead of using a mannequin as in the planning. Respondents were accompanied by husband while attending counseling activities. The majority of the respondents were patients who underwent caesarean section.

This was related to the provision of Health Social Insurance Agency (BPJS) which indicated that patients should have spontaneous labor at first level health care unit (Community Health Centre), unless no community health care is available in their area. In this research, we used postpartum maternal respondents with spontaneous labor and caesarean section on postpartum day 0 to day 2 . We found that respondents refuse to continue the counseling due to being discomfort. Therefore, we have to seek another respondent with the same criteria to meet the number of research samples.

\section{Conclusion}

Postpartum care counseling given to postpartum mothers at Wates General Hospital, Kulonprogo is significantly effective in improving postpartum mood changes for postpartum mothers.

Health workers in prenatal units should provide information through postpartum and infant care counseling for each prenatal client in the third trimester or after having parturient process so that postpartum mothers can be ready for their childbirth and baby care. Furthermore, we expect our study to be used by stakeholders in managing standard operational procedure on postpartum care. We also expect that our study be used by other researchers as references. Lastly, we expect our study to be further developed with more related researches.

\section{Acknowledgement}

We thank the Ministry of Research, Technology, and Higher Education for funding our study. We also thank LPPM Yogyakarta University which has facilitated the implementation of Wates Kulonprogo research and hospitals that have allowed the implementation of our study. We thanks all respondents of postpartum mothers who have been willing to be involved in this study.

\section{References}

Asmuji \& Indriyani, D. 2016. Family Centered
Maternity Care Model as the Strategy to Optimize Competent Mothering. Faculty of Health Sciences Muhammadiyah University. Ners, 11(1).

Basten, S. 2009. Postnatal Depression and Fertility: Future Research Directions? International Journal of Nursing Studies.

Castalino, F., Nayak, B. S. dan D'Souza, A. 2014. Knowledge and Practices of Postnatal Mothers on Newborn Care in Tertiary Care Hospital of Udupi District. Nitte University Journal of Health Science, 4(2): 98-101.

Duman, N. B. 2012. The Effect of Counseling Provided on the Second Post Partum Day Through Home Visits on Breastfeeding Success in Turkey: Randomized, Controlled Trial. Journal of Nursing Education and Practice, 2(1): 91-100.

Ichsan, B. S. \& S. 2015. Keefektifan Program Kelompok Pendamping Ibu dalam Mengubah Perilaku Ibu Menyusui. Jurnal Kesehatan Masyarakat KEMAS, 10(2): 186194.

Irawati, D. 2014. Pengaruh Faktor Psikososial dan Cara Persalinan Terhadap Terjadinya Post Partum Blues pada Ibu Nifas. Hospital Majapahit, 6(1): 1-14.

Isni, K. 2016. Dukungan Keluarga, Dukungan Petugas Kesehatan dan Perilaku Ibu Dalam Pencegahan HIV AIDS ke Bayi. Jurnal Kesehatan Masyarakat KEMAS, 11(2).

Kirana, Y. 2015. Hubungan Tingkat Kecemasan Post Partum dengan Kejadian Post Partum Blues di Rumah Sakit Dustira Cimahi. 3(1): 26.

Kusumastuti dan Diah, P. 2013. Hubungan Karakteristik Individu dengan Depresi Postpartum. Jurnal Involusi Kebidanan, 5(9): 1-17.

Marmer, L. W. dan Ariana, A. D. 2016. Persepsi terhadap Dukungan Suami pada Primipara yang Mengalami Depresi Pasca Melahirkan. Jurnal Psikologi Klinis dan Kesehatan Mental, $5(1)$.

Musfiroh, M \& Wisudaningtyas, B. L. 2014. Penyuluhan Terhadap SIkap Ibu Dalam Memberikan Toilet Training Pada Anak. Jurnal Kesehatan Masyarakat KEMAS, 9(2): 157-166

Purwati, Y. 2015. Korelasi Partisipasi Ibu Menyusui Pada Kelompok Pendamping ASI dengan Keberhasilan Pemberian ASI Eksklusif, " Jurnal Kebidanan dan Keperawatan, 11(1): 73-82.

Purwati, Y. Taufiqur Rahman, I \& Akhmadi. 2015. Pendidikan Seksual dan Perilaku Kebutuhan Pemenuhan Kebutuhan Seksual 
Pasangan Masa Kehamilan. Jurnal Kesehatan Masyarakat KEMAS, 10(2): 178-185.

Reitmanova, S. dan Gustafson, D. L. 2009. Mental health needs of visible minority immigrants in a small Urban Center: Recommendations for policy makers and service providers. Journal of Immigrant and Minority Health, 11(1): 46-56.

Rusli, R. A., Meiyuntariningsih, T. and Warni, W. E. 2011. Perbedaan Depresi Pasca Melahirkan pada Ibu Primipara Ditinjau dari Usia Ibu Hamil. INSAN, 13(1): 21-31.

Segre, L. 2010. Screening and Counseling For Postpartum Depression By Nurses: The Women's Views. MCN Am J Matern Child Nurs, 35(5): 280-285.

Setiawati, R. 2016. Pengaruh Konseling Terhadap Motivasi Ibu Melakukan Perawatan Metode
Kangguru Pada Bayi Berat Lahir Rendah. Jurnal Kesehatan Masyarakat KEMAS, 11(2). Spaulding, McCarter. D. \& Shea, S. 2016. Effectiveness of Discharge Education on Postpartum Depression. The American Journal of Maternal/Child Nursing, 41(3): 168-172.

Sunesni, Fitriyanti \& Serudji. 2015. "Artikel Penelitian Pengaruh Mobilisasi Ibu Post Partum terhadap Pengeluaran Kolostrum," Jurnal Kesehatan Andalas, 4(1), hal. 30-36.

Westall, C. 2011. "Women And Their Partners By Carolyn Westall"

Woro, K.H., et al. 2017. Substitution Program In Indonesia And Australia As Health Promotion Model At Schools. Jurnal Kesehatan Masyarakat KEMAS, 12(2) 